Richard Gitzelmann (23rd February 1930-31st October 2013)

Steinmann, Beat

DOI: https://doi.org/10.1007/s00431-014-2322-6

Posted at the Zurich Open Repository and Archive, University of Zurich ZORA URL: https://doi.org/10.5167/uzh-171961

Journal Article

Published Version

Originally published at:

Steinmann, Beat (2014). Richard Gitzelmann (23rd February 1930-31st October 2013). European Journal of Pediatrics, 173(6):695-697.

DOI: https://doi.org/10.1007/s00431-014-2322-6 


\title{
Richard Gitzelmann (23rd February 1930-31st October 2013)
}

\author{
Beat Steinmann
}

Received: 10 April 2014 / Accepted: 10 April 2014 /Published online: 27 April 2014

(C) Springer-Verlag Berlin Heidelberg 2014

Keywords Obituary $\cdot$ Gitzelmann $\cdot$ Metabolism

Richard Gitzelmann, an international pioneer in inborn errors of metabolism and promoter of newborn screening in Switzerland, passed away on October 31st 2013. He was a member of the circle of important paediatricians who shaped the development of child and adolescent medicine during the second half of the last century and helped to establish the high international reputation of Swiss paediatrics.

Richard Gitzelmann studied medicine in Zürich and completed his medical degree in 1955. His dissertation in 1956 with the title 'Glucagon Problems in Glycogen Storage Diseases' already signalled his future area of interest. From 1957 to 1960, he learned the 'tricks of the trade' in general paediatrics as a junior doctor in the University Children's Hospital Zürich, then headed by Prof. Guido Fanconi. With his special training in the USA from 1960 to 1963, he made career-shaping decisions; first, as a Research Fellow at Johns Hopkins Hospital, Baltimore, then as a Fellow at the Clinical Research Unit at Duke University, Durham.

Following his return to the Children's Hospital Zürich in 1963, he ran his own metabolic laboratory. In 1965, he defined a previously unknown metabolic block, galactose kinase deficiency, in a patient previously reported by Guido Fanconi as atypical galactosaemia. The resulting publication with the title 'Deficiency of erythrocyte galactose kinase in a patient with galactose diabetes' appeared in the Lancet making him well known in the metabolic circle almost overnight [7]. In 1967, RG qualified in the university with his thesis being a followup publication in the very first edition of Pediatric Research [8] - this paper was selected as a Citation Classic in Current

Communicated by Beat Steinmann

B. Steinmann $(\bowtie)$

University Children's Hospital, Zurich, Switzerland

e-mail: beat.steinmann@kispi.uzh.ch
Contents in 1987 [13]. In 1976, RG was appointed Professor and head of the newly founded metabolic division which he led until his retirement in 1997.

RG was an expert in inborn errors of metabolism of galactose [9, 10, 13-15], fructose [2-4, 11, 16, 19], sucrose [6] and glycogen $[1,17]$, and later also in lysosomal storage diseases $[5,18]$. His numerous publications were not merely of academic importance; rather, they were more than just 'l'art pour l'art', making a significant impact on the diagnosis and treatment of inborn errors of metabolism. Following a yearlong battle against the food industry, he, along with his colleagues Ruedi Froesch, Kurt Baerlocher and Peter Dangel, was able to ban fructose and sorbitol from commercially available infusion solutions, a victory to which several patients with unsuspected fructose intolerance thankfully owe their lives [16]. From 1965, RG was instrumentally involved in the establishment and development of newborn screening in Switzerland, a task he fulfilled with his usual pugnacity [12]. Thanks to timely introduction of treatment, many children with inherited metabolic diseases were and can be protected from the detrimental effects of their disorder or even from early death.

RG was a clinician par excellence: A sharp, disciplined observer who steadfastly and ostensively stuck to his convictions. He rigorously questioned his own results, and he confronted ensuing conclusions with clinical observations almost obsessively. He was a perfectionist to the core! If his experimental findings were incompatible with the clinical observations, his attitude was 'nature knows best' — and back to square one. Quasi as consultant to the University veterinary hospital and thanks to his sensitive acumen, he was able to describe mucolipidosis for the first time, a genetic storage disease in the shorthaired cat [5]. At the other extreme, as an all-round paediatrician, he was deputy to Prof. Andreas Fanconi, the former director of the medical clinic. 

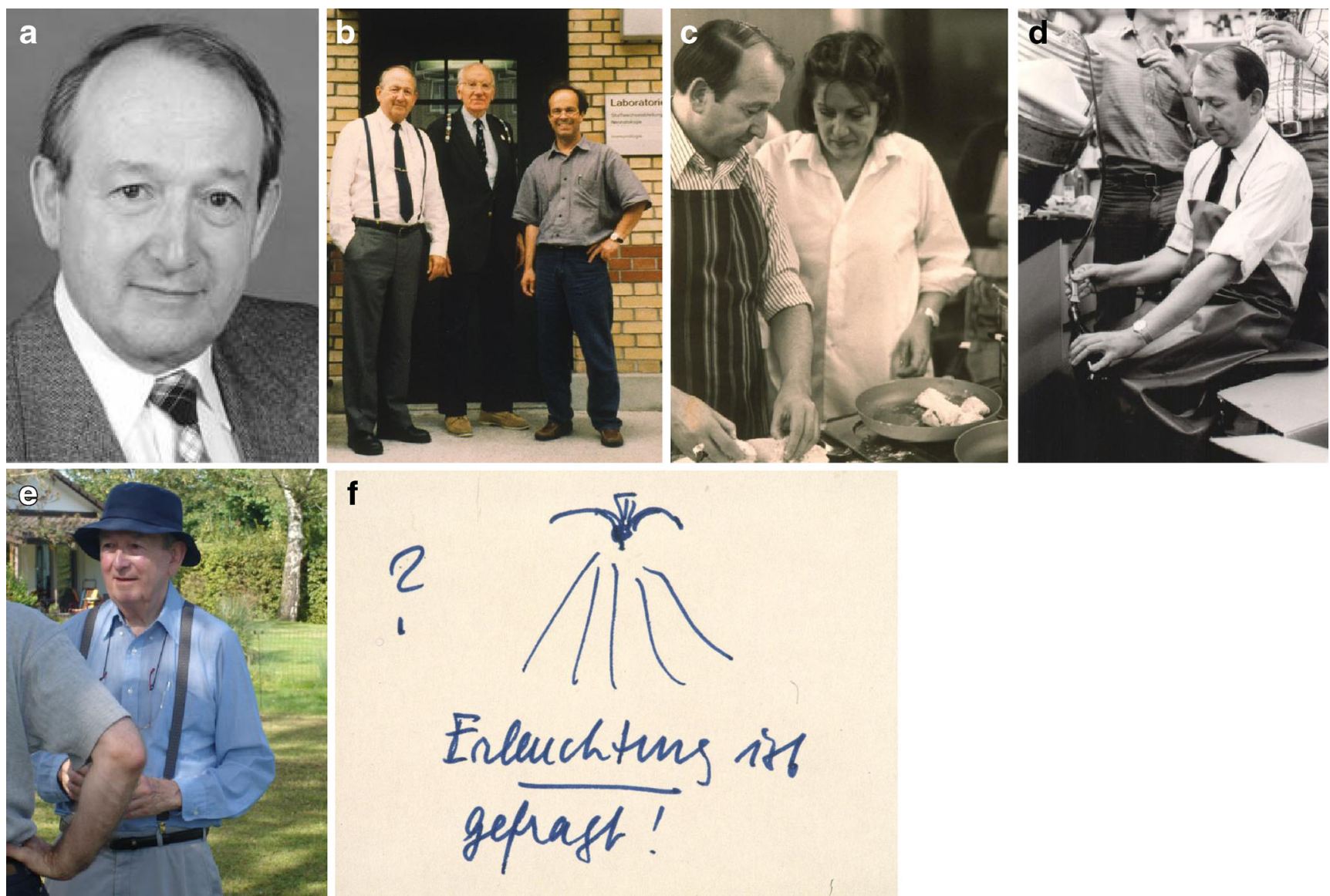

f

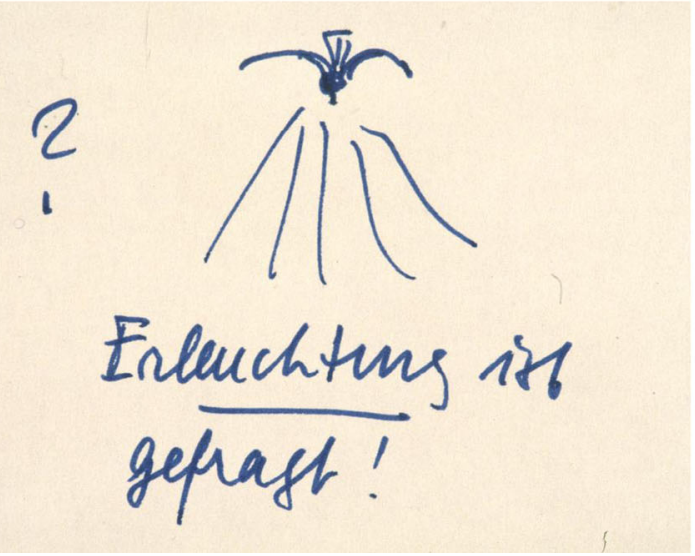

Fig. a Richard Gitzelmann, 1990; b RG, Victor McKusick and Beat Steinmann in front of his Laboratory, 1995; c RG attending a famous cooking class with Agnes Amberg, 1980; d RG as the chief of wine

bottling in his laboratory, 1979; e RG during a gathering with his former division on the Lake of Zurich, 2007; f one of RG's ironic sketches after a staff meeting, 'Enlightenment is needed', 1996

RG was also a prudent advisor of younger colleagues in helping them to decide on their academic careers. His tireless and enthusiastic involvement in undergraduate and postgraduate teaching was legendary - however, he was 'not amused' with the young ladies knitting during his lectures. As early as 1971, RG was a member of the first Curriculum Reform Committee of the Senate of the University of Zürich. He was active in the Research Committee of the University of Zurich from 1977-1985, from 1980 in the Supervising Committee of Post Graduate Courses in Experimental Medicine and Biology and in the 1970s in the Interdisciplinary Working Group on Ethical Issues Related to Abortion due to Genetic Indications.

Following his retirement, Ricco withdrew from medicine. Increasingly, he dedicated himself to drawings and water colour painting, and here too was very self-critical. He remained loyal to his former division. He participated regularly in social outings, always standing, never sitting as it had been with his standing desk in his office or at faculty meetings for many years. When it became impossible for him to leave his house due to Parkinson disease, he was happy to receive visitors at home. Ricco never ever complained about his health.

Whether as an important paediatrician, enthusiastic teacher, creative researcher or humanist with quick-wittedness and humour, Richard Gitzelmann will remain in our grateful memory.

Acknowledgments I thank Prof. Brian Fowler and Dr. Nilou SaxerCumarasamy for the help in the translation.

\section{Selected References}

1. Aynsley-Green A, Williamson DH, Gitzelmann R (1977) Hepatic glycogen synthetase deficiency. Definition of syndrome from metabolic and enzyme studies on a 9-year-old girl. Arch Dis Child 52: 573-579

2. Baerlocher K, Gitzelmann R, Nüssli R, Dumermuth G (1971) Infantile lactic acidosis due to hereditary fructose 1,6-diphosphatase deficiency. Helv Paediatr Acta 26:489-506

3. Baerlocher K, Gitzelmann R, Steinmann B, GitzelmannCumarasamy N (1978) Hereditary fructose intolerance in early childhood: a major diagnostic challenge. Survey of 20 symptomatic cases. Helv Paediatr Acta 33:465-487 
4. Boesiger P, Buchli R, Meier D, Steinmann B, Gitzelmann R (1994) Changes of liver metabolite concentrations in adults with disorders of fructose metabolism after intravenous fructose by ${ }^{31} \mathrm{P}$ magnetic resonance spectroscopy. Pediatr Res 36:436-440

5. Bosshard NU, Hubler M, Arnold S, Briner J, Spycher MA, Sommerlade HJ, von Figura K, Gitzelmann R (1996) Spontaneous mucolipidosis in a cat: an animal model of human I-cell disease. Vet Pathol 33:1-13

6. Dubs R, Steinmann B, Gitzelmann R (1973) Demonstration of an inactive enzyme antigen in sucrase-isomaltase deficiency. Helv Paediatr Acta 28:187-198

7. Gitzelmann R (1965) Deficiency of erythrocyte galactokinase in a patient with galactose diabetes. Lancet Ii:670-671

8. Gitzelmann R (1967) Hereditary galactokinase deficiency, a newly recognized cause of juvenile cataracts. Pediatr Res 1:14-23

9. Gitzelmann R (1969) Formation of galactose-1-phosphate from uridine diphosphate galactose in erythrocytes from patients with galactosemia. Pediatr Res 3:279-286

10. Gitzelmann R (1972) Deficiency of uridine diphosphate galactose 4epimerase in blood cells of an apparently healthy infant. Prelim Commun 27:125-130

11. Gitzelmann R, Steinmann B, Bally C, Lebherz HG (1974) Antibody activation of mutant human fructosediphosphate aldolase $\mathrm{B}$ in liver extracts of patients with hereditary fructose intolerance. Biochem Biophys Res Commun 59:1270-1277

12. Gitzelmann R (1982) Rationales for genetic screening. Prog Clin Biol Res 103 Pt B:425-436
13. Gitzelmann R (1987) Hereditary galactokinase deficiency, a newly recognized cause of juvenile cataracts. This Week's Citation Classics, Current Contents 30: 14 (only)

14. Kalaydjieva L, Perez-Lezaun A, Angelicheva D, Onengut S, Dye D, Bosshard NU, Jordanova A, Savov A, Yanakiev P, Kremensky I, Radeva B, Hallmayer J, Markov A, Nedkova V, Tournev I, Aneva L, Gitzelmann R (1999) A founder mutation in the GK1 gene is responsible for galactokinase deficiency in Roma (Gypsies). Am J Hum Genet 65:1299-1307

15. Mitchell B, Haigis E, Steinmann B, Gitzelmann R (1975) Reversal of UDP-galactose 4-epimerase deficiency of human leukocytes in culture. Proc Natl Acad Sci U S A 72:5026-5030

16. Müller-Wiefel DE, Steinmann B, Holm-Hadulla M, Wille L, Schärer K, Gitzelmann R (1983) Infusionsbedingtes Nieren- und Leberversagen bei undiagnostizierter hereditärer FructoseIntoleranz [Infusion-associated kidney and liver failure in undiagnosed hereditary fructose intolerance]. Dtsch Med Wochenschr 108:985-989

17. Orho M, Bosshard NU, Buist NR, Gitzelmann R, Aynsley-Green A, Blümel P, Gannon MC, Nuttall FQ, Groop LC (1998) Mutations in the liver glycogen synthase gene in children with hypoglycemia due to glycogen storage disease type 0. J Clin Invest 102:507-515

18. Steinmann B, Mieth D, Gitzelmann R (1981) A newly recognized cause of low urinary estriol in pregnancy: multiple sulfatase deficiency of the fetus. Gynecol Obstet Investig 12:107-109

19. Steinmann B, Gitzelmann R (1981) The diagnosis of hereditary fructose intolerance. Helv Paediatr Acta 36:297-316 